\title{
ETHNOPHARMACOLOGICAL STUDIES OF TRIBULUS TERRESTRIS (LINN). IN RELATION TO ITS APHRODISIAC PROPERTIES
}

\author{
${ }^{1}$ Manish Mathur* and S. ${ }^{2}$ Sundaramoorthy \\ ${ }^{1}$ Plant Ecology Section, Division of Natural Resources and Environment \\ Central Arid Zone Research Institute (CAZRI), Jodhpur, India \\ ${ }^{2}$ Jai Narain Vyas University, Jodhpur India \\ *E-mail: ravi_mm2099@yahoo.com
}

\begin{abstract}
Synergism and antagonism impact of different plant metabolites present in crude fruit extract of Tribulus terrestris 'the herbal Viagra' have been studied. Variability in plant composition, biomass and metabolites concentration in different modules was significantly contributed by spatial factor. However the edhaphic parameters also changes with both spatial and temporal factors significantly. Fruit is the officinal part and the fruit production significantly related with soil nitrogen $(\mathrm{P}<0.01)$, whereas the soil nitrogen and $\mathrm{pH}$ also influenced the alkaloid content in fruit $(\mathrm{P}<0.05)$. The linear relation between fruit protein and fruit alkaloid $(\mathrm{P}<0.01)$ also observed and the relationship in between different soil parameters were established. Bioassay work confirmed its aphrodisiac properties, and site III is suggested for maximum biomass and high concentration of different metabolites.
\end{abstract}

Key word: Tribulus terrestris, community compostion, modular biomass, steroidal saponin, soil nitrogen, sperm density.

\section{Introduction}

Nearly all culture, from ancient times, has used plants as a source of medicine. In many developing countries, traditional medicines are still the mainstay of health care and most of the drugs and the resultant remedy come from plants. In developed countries, many people are turning to herbal remedies, especially for minor ailments, and modern scientific medicine still depends on plants, and the knowledge for some essential drugs. People in India and China are known to have used plant in organized health care regimes for over 5,000 years (Mukherjee, 2004).

In addition to high population growth in many developing countries, the other fact that has come in light is that large cohorts of men in the reproductive age are in fact infertile (Marimuthu et al. 2003). Evidence of deteriorating semen quality was reported by (Auger 1995; Irvine et al. 1996 and Mathur, 2012). Our review of literature indicates that the male infertility problems are increasing day by day due to modern life style, environmental, and geographical factors. The plant based medicines are the most suitable and safe mode of treatment of male infertility problems (Pallavi et al. 2011 and Mathur, 2012). Clinical studies of aphrodisiac plants have been conducted by several workers at different parts of world (Qureshi et al. 1989; Ageel et al. 1994; Kumar et al. 2000; Suja et al. 2002; Gautharman et al. 2002, 2003; Ang et al. 2003; Ramachandran et al. 2004; Mathur. 2005; Mathur and Sundaramoorthy, 2006 and Mathur et al. 2008). Most of these studies either based on it's active components and/ or on application of crude plant extract. As it is evident the beneficial effects of plant material are typically for the effect of secondary products present in plants. In natural ecosystem, species separated on the basis of their secondary product that contributes to the development or modification of the existing ecological balance (Bernath, 2002). Most of the secondary plant products changes with environmental, spatial, communities' organization and modules factors (Mathur and Sundaramoorthy, 2009). Therefore, once the medicinal properties of a particular plant species established, these factors are very important for the large scale in term of biomass, and active compounds.

Drug plants, as a first approximation, are generally assumed to owe their efficacy to the high concentration of some constitute that may be isolated and characterized. The administration of this pure constitute should then, theoretically, produce exactly the same pharmacological effect as the original plant. There may be some cases where the above paradigm fits the facts. However, majority of plants regarded as medicinal are known to be consumed on the basis of traditional practice without the knowledge of its active components or their concentrations (Mathur and Sundaramoorthy, 2006).

The amount of each metabolites and element contained within a plant varies with the type of plant, its stage of maturity and the environmental conditions in which it is growing. The variability in concentration of different plant metabolites caused by various temporal and spatial factors, that are important for medicinal plants cultivation and collection of modules and such factors should be analyzed with pharmacological purposes.

Tribulus terrestris (Linn). Belongs to family Zygophyllaceae and known as Puncture- vine, - (English), "Gokhru” and "Chota Gokhru" (Hindi) and "Goksharu" - (Sanskrit). It is a cosmopolitan species distributed throughout the warm regions of the globe (Verdu and Mas, 2006). It is found throughout India ascending to 3,385 meters. In eastern Rajasthan this plant have been reported by various workers like Ratnam (1951), Ratnam and Joshi (1952), Bakshi (1954), Nair (1956), Nair and Nathawat (1957), and Nair and Malhotra (1961). It is a prostrate, spreading herb particularly adapted to dry region, which produce a fruit with sharp, rigid spines. The entire plant, particularly the fruit is used in traditional medicine (regards as herbal Viagra). 
Review of literature suggested that several pharmacological and phytochemical (particularly dealing with steroidal saponin and phytosterol) studies have been carried out from various parts of the world so as to identify the chemical constitutes. It is further evident that very few scientific studies have been conducted with a view of biology that formed the basis detailed ecological, phytochemical and pharmacological investigations in relation to its aphrodisiac properties. Therefore, present investigation deals with holistic approach for such an important medicinal plant.

\section{Material and Method Site selection}

In and around Jodhpur 5 sites (Table. 1) have been selected. Each site were contrasting to other sites in respect of its community, soil and landscape.

Table 1: Site locations for T. terrestris

\begin{tabular}{|l|l|l|}
\hline Site Name & Latitude & Longitude \\
\hline Jalamand (I) & $26^{0} 12^{\prime} 33.7^{\prime \prime}$ & $73^{0} 4^{\prime} 8.4^{\prime \prime}$ \\
\hline College (II) & $26^{0} 14^{\prime} 31.6^{\prime \prime}$ & $73^{0} 01^{\prime} 21.1^{\prime \prime}$ \\
\hline Kailana (III) & $26^{0} 18^{\prime} 47.0^{\prime \prime}$ & $72^{0} 60^{\prime} 35.1^{\prime \prime}$ \\
\hline Choka (IV) & $26^{0} 17^{\prime} 2.5^{\prime \prime}$ & $72^{0} 56^{\prime} 5.9^{\prime \prime}$ \\
\hline Diger (V) & $26^{0} 20^{\prime} 58.9^{\prime \prime}$ & $73^{0} 3^{\prime} 57.2^{\prime \prime}$ \\
\hline
\end{tabular}

\section{Vegetation sampling}

The quadrat studies were carried out for both annuals $(1 \mathrm{x} 1 \mathrm{~m})$ and perennials $(5 \mathrm{x} 5)$ plants according to (Kent and Cooker, 1992). The different diversity indexes like Species richness (Menhinick, 1964) Simpson index (1949) Shannon and Weaver index and Evenness (Pielou, 1966) were studied. The percent cover was calculated by following formula.

Density of plant X Average cover

Percent cover $=$

$$
\text { Quadrat area }
$$

\section{Biomass studies}

The above and belowground biomass was estimated by using random sampling during rainy season. The plants were uprooted in fix numbers (fifteen) and then washed using mild tap water to remove foreign material. Then the harvested materials were separated module wise viz., root, stem, leaves, and fruit, air-dried and weighed using electronic balance (accuracy $0.001 \mathrm{~g}$ ). Data were statistical treated with randomized block design.

\section{Phytochemical studies}

Different primary, secondary metabolites and minerals like protein, sugars, phenol, steroidal saponin, alkaloids, Zn and Fe were quantified. The estimation was carried out in all modules.

Steroidal saponin: Total steroidal saponins were estimated by spectrophotometric method suggested by Baccou et al. (1977). Dried (air), powdered plant materials were extracted in Soxlet with 90\% alcohol. The characteristic colour was developed using ethyl acetate and anisaldehyde reagents.

Protein: The plant protein was estimated by Bradford (1976) by using coomasie brilliant blue G250 dye and saline phosphate- buffer. The standard was prepared with Lysozyme.

Phenol: Total phenol was estimated by Folin-Ciocalteau reagent. This estimation based on the principle that phenols react with phosphomolydbic acid in Folin-Ciocalteau reagent in alkine medium and produce blue colored complex (molybdenum blue). Standard was prepared with caticol phenol.

Alkaloids: Total alkaloid content was quantified according to Higuchi and Bodin (1961). Dried (air), powdered plant material was extracted with $95 \%$ alcohol. Ethanolic extract was concentrated by distillation and the slurry so obtained was stirred with 7 percent citric acid. Aqueous acidic extracts were basified with liquid Ammonia to $\mathrm{pH} 7$ and the liberated alkaloids were recovered through extraction with chloroform in a separating funnel. The chloroform fraction was concentrated using water bath and dried completely that furnished total alkaloids. The computation of percent yield was based on gravimetric method. However, their identity as alkaloids was confirmed by positive colors test with Dragendroff's, Mayer and Wagner's reagent (Daniel, 1991). 
Table 2: Phytodiversity studies at the various habitats of T. terrestris

\begin{tabular}{|c|c|c|c|c|c|c|c|c|c|c|c|c|c|c|c|}
\hline \multirow[t]{2}{*}{ Parameters } & \multicolumn{3}{|l|}{ I } & \multicolumn{3}{|l|}{ II } & \multicolumn{3}{|l|}{ III } & \multicolumn{3}{|l|}{ IV } & \multicolumn{3}{|l|}{$\mathrm{V}$} \\
\hline & Rain & Winter & Summer & Rain & Winter & Summer & Rain & Winter & Summer & Rain & Winter & Summer & Rain & Winter & Summer \\
\hline RIV (T. terrestris) & 20.84 & 7.77 & - & 20.61 & 22.06 & - & 24.56 & 7.59 & - & 27.82 & 15.42 & - & 35.72 & 14.66 & - \\
\hline \multicolumn{16}{|c|}{ Vegetation Indexes (5X 5 m) } \\
\hline Species Richness & 0.45 & 0.58 & 0.48 & 0.33 & 0.77 & 0.66 & 0.632 & 0.83 & 0.58 & 1.30 & 1.38 & 0.689 & - & - & - \\
\hline $\begin{array}{l}\text { Shannon and } \\
\text { Weaver index }\end{array}$ & 0.74 & 0.56 & 0.54 & 0.68 & 1.39 & 0.52 & 0.67 & 0.69 & 1.06 & 1.48 & 0.21 & 0.39 & - & - & - \\
\hline Simpson index & 0.58 & 0.62 & 0.64 & 0.50 & 0.28 & 0.65 & 0.52 & 0.50 & 0.35 & 0.24 & 0.21 & 0.39 & - & - & - \\
\hline Evenness & 1.23 & 1.86 & 1.81 & 2.29 & 1.99 & 1.75 & 2.23 & 2.30 & 2.22 & 2.13 & 2.23 & 2.09 & - & - & - \\
\hline \multicolumn{16}{|c|}{ Vegetation Indexes (1X $1 \mathrm{~m}$ ) } \\
\hline Species Richness & 0.625 & 0.78 & 0.625 & 0.562 & 1.19 & 0.632 & 0.686 & 0.560 & 0.45 & 0.798 & 0.675 & 0.639 & 0.875 & 0.638 & 0.378 \\
\hline $\begin{array}{l}\text { Shannon and } \\
\text { Weaver index }\end{array}$ & 1.70 & 1.53 & 1.05 & 2.06 & 2.04 & 0.529 & 0.23 & 1.45 & 0.99 & 1.93 & 1.36 & 0.69 & 1.18 & 1.69 & 0.120 \\
\hline Simpson index & 0.22 & 0.271 & 0.35 & 0.156 & 0.133 & 0.654 & 0.184 & 0.30 & 0.40 & 0.207 & 0.30 & 0.50 & 0.46 & 0.195 & 0.94 \\
\hline Evenness & 1.80 & 1.97 & 2.2 & 1.97 & 2.26 & 1.75 & 0.28 & 1.87 & 2.08 & 1.85 & 1.95 & 2.29 & 1.39 & 2.18 & 0.39 \\
\hline
\end{tabular}


Mathur and Sundaramoorthy Afr J Tradit Complement Altern Med. (2013) 10(1):83-94 86 http://dx.doi.org/10.4314/ajtcam.v10i1.12

Sugar: The soluble and insoluble sugars were estimated from dried plant material using the principle of hydroxymethyl furfurial reaction with anthrone to produce green color (Plummer, 1971). Aqueous alcoholic soluble sugar part was considered as soluble and the hydrolyzed part as insoluble. The results are expressed in $\mathrm{mg} \mathrm{g}^{-1}$.

Zinc and Iron: Zinc and iron in different plant modules have been quantified by tri acid digestion followed by Atomic Absorption Spectrophotometer measurement.

All the phytochemical data were treated with two (sites and plant parts) factor strip plot design (Gomez and Gomez, 1984)

\section{Soil analysis}

Samples were collected from surface and from $30 \mathrm{~cm}$ depth. Soil textures were estimated using different types of sieves. The soil moisture was estimated immediately after the sampling, while prior to other parameters analyses; the samples were air-dried and sieved through $2 \mathrm{~mm}$ sieve (Pandeya et al., 1968). The water- soil suspension (5:1) was used to measure EC and $\mathrm{pH}$ with the respective Digital Meters at room temperature. Organic carbon determined by modified Walkley and Black's method (Jakson, 1973). Total nitrogen in soil was estimated by microkjheldahl method as described by Jakson (1973). Available phosphorus estimation was based on the development of molybdenum blue colour as described by Allen et al. (1976). Data were treated with three (sites, seasons and depths) factors strip-plot design.

Table:3: Biomass studies of various modules of T. terrestris

\begin{tabular}{|l|l|l|}
\hline Modules & Biomass (g) \\
\hline & Range & Higher biomass/site. \\
\hline Root & $5.34-10.13$ & I \\
\hline RBD/Source of variation & Mean squares & Computed F value \\
\hline Sites & 0.38 & $5.14^{* *}$ \\
\hline Stem & $28.56-55.41$ & III \\
\hline Sites & 7.30 & $1.30^{\text {ns }}$ \\
\hline Leaves & $39.12-84.7$ & III \\
\hline Sites & 20.69 & $1.66^{\text {ns }}$ \\
\hline Fruit & $12.91-75.75$ & III \\
\hline Sites & 44.41 & $8.36^{* *}$ \\
\hline
\end{tabular}

** = significant at 0.01 level; * = significant at 0.05 level; ns = non significant

Table 4: Different seed parameters and plant cover of $T$. terrestris

\begin{tabular}{|l|l|l|}
\hline Parameters & Range & Higher values/site/seasons \\
\hline Fruit out put & $500-1673$ & III \\
\hline $\begin{array}{l}\text { RBD results/ } \\
\text { Source of variation }\end{array}$ & Mean squares & Computed F value \\
\hline Sites & 11306.18 & $4.42^{* *}$ \\
\hline Cocoi weight (g/100) & $3.18-3.99$ & II \\
\hline $\begin{array}{l}\text { RBD results/ } \\
\text { Source of variation }\end{array}$ & Mean squares & Computed F value \\
\hline Sites & 0.36 & $130.87^{* *}$ \\
\hline Percent cover $\left.\mathbf{( m}^{2}\right)$ & $0.3-3.23$ & II \\
\hline $\begin{array}{l}\text { RBD results/ } \\
\text { Source of variation }\end{array}$ & Mean squares & Computed F value \\
\hline Sites & 0.18 & $9.68^{* *}$ \\
\hline
\end{tabular}

** = significant at 0.01 level; * = significant at 0.05 level; $\mathrm{ns}=$ non significant

Table 5: Different primary metabolites in various modules of T. terrestris 
Mathur and Sundaramoorthy Afr J Tradit Complement Altern Med. (2013) 10(1):83-94

http://dx.doi.org/10.4314/ajtcam.v10i1.12

\begin{tabular}{|c|c|c|c|c|c|c|}
\hline & \multirow{2}{*}{\multicolumn{2}{|c|}{ Protein $\left(\mathrm{mg} \mathrm{g}^{-1}\right)$}} & \multicolumn{4}{|l|}{ Sugars $\left(\mathrm{mg} \mathrm{g}^{-1}\right)$} \\
\hline & & & \multicolumn{2}{|l|}{ Soluble } & \multicolumn{2}{|l|}{ Insoluble } \\
\hline Modules & Range & $\begin{array}{l}\text { Modules } \\
\text { with } \\
\text { higher } \\
\text { conc./site }\end{array}$ & Range & $\begin{array}{l}\text { Modules } \\
\text { with } \\
\text { higher } \\
\text { conc./site }\end{array}$ & Range & $\begin{array}{l}\text { Modules } \\
\text { with } \\
\text { higher } \\
\text { conc./site }\end{array}$ \\
\hline Root & $1.7-2.94$ & \multirow[t]{4}{*}{ Fruit/IV } & $3.4-12.47$ & \multirow[t]{4}{*}{ Fruit/III } & $2.81-5.44$ & \multirow[t]{4}{*}{ Fruit/V } \\
\hline Stem & $1.38-3.69$ & & $1.94-10.87$ & & $0.72-6.7$ & \\
\hline Leaves & $3.13-4.1$ & & $0.94-7.25$ & & $1.5-4.97$ & \\
\hline Fruit & $2.26-5.99$ & & $7.66-25.03$ & & $10.17-18.8$ & \\
\hline $\begin{array}{l}\text { ANOVA } \\
\text { results/ } \\
\text { Source of } \\
\text { variation }\end{array}$ & Mean squares & $\begin{array}{l}\text { Computed } \\
\text { F value }\end{array}$ & Mean squares & $\begin{array}{l}\text { Computed } \\
\text { F value }\end{array}$ & Mean squares & $\begin{array}{l}\text { Computed } \\
\text { F value }\end{array}$ \\
\hline Sites & 0.85 & $6.87^{*}$ & 96.62 & $65.65^{* *}$ & 45.83 & $39.68^{* *}$ \\
\hline Plant Part & 12.16 & $72.14^{* *}$ & 392.4 & $266.7^{* *}$ & 419.4 & $513.74^{* *}$ \\
\hline $\begin{array}{l}\text { Sites X Plant } \\
\text { part }\end{array}$ & 3.28 & $19.46^{* *}$ & 58 & $39.42^{* *}$ & 24.83 & $30.42^{* *}$ \\
\hline
\end{tabular}

\section{Pharmacological studies}

With prior reconnaissance of the traditional knowledge, fruit part of $T$. terrestris being used for drug preparation, the extract was prepared with ethanol in reflux condenser. For dosages determination, a pilot experiment was set up for evaluating the nature of drug. A group of 3 animals was taken for each drug and dosages (500 $\mathrm{mg} \mathrm{kg}^{-1}$ body weight) were prepared accordingly. After 24 hours of last dose, all animals were scarified under prolonged ether anesthesia. The reproductive track were taken out and trimmed free of fat and cleaned of adherent tissue. Each organ was weighted separately on electronic balance. The reproductive organs considered in the present study were testis, epididymis, ventral prostate and seminal vesicle. Some vital organs such as liver, kidney and heart also excised and weighed. All the organs were fixed in Bovine fixture.

\section{Sperm dynamics}

Sperm Motility: The assessment was performed for each of the male animals in experimental groups. Sperm count of motile and total sperm was determined using known quantity (100mg in $2 \mathrm{ml}$ physiological saline) of Cauda epididymis. The sperm motility was done by using Neuber's chamber of haemocytometer.

Sperm density: The Cauda epididymal and testicular sperm counts were determined by routine procedure and expressed as million/ml of suspension. Homogenized suspension was diluted with sodium bicarbonate for taking sperm count; Prashad et al. (1972).

\section{Histological studies}

For histological observation, Bovin’s fixed reproductive organs along with vital organs were cut in to small pieces and processed through ethanol xylene series. The paraffin embedding was followed by section cutting (5 $\mu \mathrm{m}$ thicknesses) and staining (Harris haemotoxylin and eosin). The stained sections were examined for histological changes.

\section{Results \\ Vegetation studies}

Phyto-sociological survey suggested drought escaping nature of $T$. terrestris that lavishly bloom during the high moisture content. The dominated (Relative Importance Value; RIV) shrub species in the study sites were Crotolaria burhia (68.19), Prosopis juliflora (66.99) and Fagonia cretica (59.23). Anthropogenic activities exert negative impact on population of Capparis decidua and Prosopis cineraria, Zizyphus nummularia was recorded only at site III and IV site, whereas no tree or shrub species were recorded at site $\mathrm{V}$ site. The maximum relative importance value in $1 \mathrm{x} 1 \mathrm{~m}$ quadrat study was recorded for Cyprus rotundus (75) and the minimum was observed for Dactyloctenium sindicum (2.60). The maximum value for $T$. terrestris (35.72) was recorded at site $\mathrm{V}$ during wet period.

High richness values (Table 2) for shrub species were recorded during winter period at all sites and it was recorded maximum (1.38) at site IV. The herbaceous species richness was also recorded maximum (1.19) during winter period at site II. Shannon weaver index values for both shrubs and herbs species were recorded maximum $(1.48,2.06)$ during rainy period at sites IV and II, respectively. In both types of quadrat studies the Simpson index was observed maximum $(0.65,0.94)$ during summer period at sites II and V, respectively. The evenness for perennials (Table 2) ranges from 1.23 at site I in rainy period to 2.30 at site III in winter period. For annuals, the minimum (0.39) and maximum (2.29) evenness were observed during summer period at sites V and IV, respectively.

Biomass studies 
The root biomass was in range of $5.34-10.13 \mathrm{~g}$ and recorded maximum at site I. Among the different modules, the highest biomass was obtained from leaf part and it was in the range of $39.12-84.7 \mathrm{~g}$, followed by fruit, stem and root. The stem and fruit biomass were in the range of 28.56-55.41; $12.91-75.75$, respectively and their maximum biomass was recoded from same site III (Table 3). RBD analyses showed that the site factors contributed the variability in root and fruit biomass $(\mathrm{P}<0.01)$, whereas this factor was non-significant for stem and leaves (Table 3). The fruit output was in range of $500-1673$ and the maximum fruit production was recorded from site III. The cocoi weight $(g / 100)$ was in the range of 3.18- 3.99, the maximum weight was recorded from site II. The highest percent cover $\left(3.23 \mathrm{~m}^{2}\right)$ was observed at site II and it was in the range of $0.3-3.23$. Statistically the site factor contributed the variations in fruit output, cocoi weight, and percent cover $(\mathrm{P}<0.01$; Table 4).

\section{Phytochemical analysis}

The protein content $\left(\mathrm{mg} \mathrm{g}^{-1}\right)$ in different modules revealed higher concentration in fruit at site IV and factors i.e. plant part and its interaction with site factor contributed significantly for the variation $(\mathrm{P}<0.01)$, with lesser extent by site factor $(\mathrm{P}<0.05)$. In officinal part (fruit), the protein content was in the range of 2.26-5.99. Among different modules, the least protein content was recorded in root part (1.7-2.94; Table 5). Both soluble and insoluble sugars (mg g-1) were recorded maximum in fruit part at sites III and V. In different modules the soluble and insoluble sugar contents were in order of fruit> root $>$ stem $>$ leaves, fruit $>$ stem $>$ root $>$ leaves, respectively. The variations in both types of sugars was within the randomness limit, however, site, and module factors contributed significantly $(\mathrm{P}<0.01$; Table 5).

The steroidal saponin $\left(\mu \mathrm{g} \mathrm{g}^{-1}\right)$ content in different modules was in the order of fruit> root> leaves> stem. In fruit it was in the range of 199.35- 666.4 and the maximum steroidal saponin production from fruit part was recorded at site II. The module wise phenolic content (root $>$ stem $>$ leaves $>$ fruit) showed the reverse compare to protein. In root part it was in the range of 21.99- 111.4. The fruit collected form site IV possessed the maximum alkaloid content and it was in the range of 0.37-1.66 percent (Table 6). The variations in these important secondary metabolites were significantly contributed by three factors: site, modules and their interaction $(\mathrm{P}<0.01$; Table 6).The quantitative analysis of micronutrient like $\mathrm{Zn}$ and $\mathrm{Fe}$ revealed spatial and modular variations $(\mathrm{P}<0.01)$. The maximum zinc $\left(1.29 \mathrm{mg} \mathrm{g}^{-1}\right)$ was recorded in root collected from site $\mathrm{I}$. Fruit collected from site I also possessed the maximum (3.105 $\mathrm{mg} \mathrm{g}^{-1}$ ) iron content. (Table 7).

\section{Soil analysis}

The soil texture result (Table 8) indicates that at sites (I, II, III, and V) root zone of $T$. terrestris preferred the soil particles in the following order sand $>$ clay $>$ silt $>$ gravel, however, at site IV it was in the order of sand $>$ clay $>$ gravel $>$ silt. The soil moisture at both levels (surface and $30 \mathrm{~cm}$ ) was in the range of 0.3-8.9 and 0.9-12, respectively and their maximum values were recorded during rainy period at sites $\mathrm{V}$ and $\mathrm{I}$. The maximum $(9.21) \mathrm{soil} \mathrm{pH}$ at surface and $30 \mathrm{~cm}(9.33)$ was also recorded during rainy period from sites IV and V, correspondingly.

Electric conductivity (EC) at surface soil was higher at site III during rainy period and it was in the range of 0.081 $0.5 \mathrm{msm}$, while at $30 \mathrm{~cm}$ the site IV during rainy period showed higher EC (0.13-0.62 msm; Table 9). The soil organic carbon

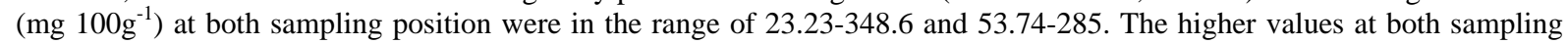
positions were recorded at site $\mathrm{V}$ during summer period. The soil nitrogen was in the range of 27.9-73.1 (surface) and 16.1$91.8(30 \mathrm{~cm}$.). The soil of site I during summer period showed higher nitrogen content at both horizon and it was in the range of 14.8-395; 12-125, respectively. Similar to nitrogen soil collected from site V also showed higher soil P (mg $100 \mathrm{~g}^{-1}$ )

Table 6: Different secondary metabolites in various modules of $T$. terrestris

\begin{tabular}{|c|c|c|c|c|c|c|}
\hline & \multicolumn{2}{|c|}{ Steroidal saponin $\left(\mu \mathrm{g} \mathrm{g}^{-1}\right)$} & \multicolumn{2}{|l|}{ Phenol $\left(\mu \mathrm{g} \mathrm{g}^{-1}\right)$} & \multicolumn{2}{|l|}{ Alkaloids } \\
\hline Modules & Range & $\begin{array}{l}\text { Modules } \\
\text { with } \\
\text { higher } \\
\text { conc./site }\end{array}$ & Range & $\begin{array}{l}\text { Modules } \\
\text { with } \\
\text { higher } \\
\text { conc./site }\end{array}$ & Range & $\begin{array}{l}\text { Modules } \\
\text { with } \\
\text { higher } \\
\text { conc./site }\end{array}$ \\
\hline Root & $96.40-200$ & \multirow[t]{4}{*}{ Fruit/II } & $21.99-111.4$ & \multirow[t]{4}{*}{ Root/II } & $0.45-0.69$ & \multirow[t]{4}{*}{ Fruit/IV } \\
\hline Stem & $73.78-94.96$ & & $22.39-107.2$ & & $0.45-0.81$ & \\
\hline Leaves & $60.19-185.17$ & & $33.56-59.62$ & & $0.51-1.34$ & \\
\hline Fruit & $199.35-666.4$ & & 25.37- 52.67 & & $0.37-1.66$ & \\
\hline $\begin{array}{l}\text { ANOVA } \\
\text { results/ } \\
\text { Source of } \\
\text { variation }\end{array}$ & Mean squares & $\begin{array}{l}\text { Computed } \\
\text { F value }\end{array}$ & Mean squares & $\begin{array}{l}\text { Computed } \\
\text { F value }\end{array}$ & Mean squares & $\begin{array}{l}\text { Computed } \\
\text { F value }\end{array}$ \\
\hline Sites & 2432 & $553.4^{* *}$ & 1300 & $7.18^{* *}$ & 0.235 & $7.10^{* *}$ \\
\hline Plant Part & 2503 & $2088.7^{* *}$ & 3878 & $21.56^{* *}$ & 0.5427 & $15.05^{* *}$ \\
\hline $\begin{array}{l}\text { Sites X } \\
\text { Plant part }\end{array}$ & 3411 & $83.5^{* *}$ & 1625 & $9.04^{* *}$ & 0.301 & $8.35^{* *}$ \\
\hline
\end{tabular}

** = significant at 0.01 level; * = significant at 0.05 level; $\mathrm{ns}=$ non significant 
Mathur and Sundaramoorthy Afr J Tradit Complement Altern Med. (2013) 10(1):83-94 89 http://dx.doi.org/10.4314/ajtcam.v10i1.12

Table 7: Different micro element in various modules of $T$. terrestris

\begin{tabular}{|c|c|c|c|c|}
\hline & \multicolumn{2}{|l|}{ Zinc (mg g $\left.{ }^{-1}\right)$} & \multicolumn{2}{|l|}{ Iron $\left(\mathrm{mg} \mathrm{g}^{-1}\right)$} \\
\hline Modules & Range & $\begin{array}{l}\text { Modules with higher } \\
\text { conc./site }\end{array}$ & Range & $\begin{array}{l}\text { Modules with higher } \\
\text { conc./site }\end{array}$ \\
\hline Root & $0.001-1.29$ & \multirow[t]{4}{*}{ Root/I } & $0.67-1.31$ & \multirow[t]{4}{*}{ Fruit/I } \\
\hline Stem & $0.01-0.23$ & & $0.256-0.713$ & \\
\hline Leaves & $0.003-0.071$ & & $0.48-1.32$ & \\
\hline Fruit & $0.002-0.021$ & & $1.17-3.105$ & \\
\hline $\begin{array}{l}\text { ANOVA results/ } \\
\text { Source of variation }\end{array}$ & Mean squares & Computed F value & Mean squares & Computed F value \\
\hline Sites & 0.266 & $377.31^{* *}$ & 0.48 & $8.33^{* *}$ \\
\hline Plant Part & 0.350 & $471.56^{* *}$ & 5.14 & $74.56^{* *}$ \\
\hline Sites X Plant part & 0.207 & $278.81^{* *}$ & 1.30 & $18.86^{* *}$ \\
\hline
\end{tabular}

** = significant at 0.01 level; * = significant at 0.05 level; ns = non significant

content but during rainy period and it was in the range of 6.05-70.27 and 6.02-67.85. The variations in the edaphic factors undertaken in the present investigation significantly contributed by all three factors i.e. sites, seasons and depth and their interactions $(\mathrm{P}<0.01$; Table 10). However, interaction between seasons and depth was non-significant for EC.

Table 8: Soil texture at the sites of $T$. terrestris

\begin{tabular}{|c|c|c|c|c|c|c|c|c|c|c|}
\hline \multicolumn{11}{|c|}{ T. terrestris sites } \\
\hline \multirow{2}{*}{ Soil type } & \multicolumn{2}{|l|}{ I } & \multicolumn{2}{|l|}{ II } & \multicolumn{2}{|l|}{ III } & \multicolumn{2}{|l|}{ IV } & \multicolumn{2}{|l|}{$\mathrm{V}$} \\
\hline & Surface & $30 \mathrm{~cm}$ & Surface & $\begin{array}{l}30 \\
\mathrm{~cm}\end{array}$ & Surface & $30 \mathrm{~cm}$ & Surface & $30 \mathrm{~cm}$ & Surface & $30 \mathrm{~cm}$ \\
\hline Clay & 29.83 & 25.39 & 30.99 & $\begin{array}{l}35.7 \\
2\end{array}$ & 24.47 & 36.56 & 34.48 & 21.05 & 29.73 & 30.61 \\
\hline Silt & 27.48 & 26.26 & 17.89 & $\begin{array}{l}17.7 \\
8\end{array}$ & 5.71 & 3.72 & 4.45 & 2.81 & 9.27 & 11.96 \\
\hline Sand & 30.51 & 30.23 & 45.01 & $\begin{array}{l}40.5 \\
4\end{array}$ & 68.4 & 57.68 & 54.41 & 68.69 & 58.39 & 54.41 \\
\hline Gravel & 12.21 & 17.47 & 5.52 & 4.46 & 4.42 & 2.04 & 6.66 & 7.45 & 2.51 & 3.02 \\
\hline
\end{tabular}

\section{Bioassay}

The data revealed that crude drug of $T$. terrestris fruit support the body weight and it increased compared to control The bioassay work also showed that crude drug of this plant support some of the reproductive organs like seminal vesicle (731.57 $\mathrm{mg} / 100 \mathrm{~g}$ body wt.), ventral prostrate (126.31 mg/100g body wt.). Whereas the oral application T. terrestris produced negative effect on weight of testis and epididymis. The drug also produces positive impact on some of the vital body organs

Table 9: Soil parameters at the sites of T. terrestris

\begin{tabular}{|c|c|c|c|c|c|c|}
\hline & \multicolumn{2}{|c|}{ Moisture (\%) } & \multicolumn{2}{|l|}{$\mathrm{pH}$} & \multicolumn{2}{|l|}{ EC $\mathrm{mSm}$} \\
\hline Sampling & Range & $\begin{array}{l}\text { Higher } \\
\text { conc./site/s } \\
\text { eason }\end{array}$ & Range & $\begin{array}{l}\text { Higher conc. / } \\
\text { site/seasons }\end{array}$ & Range & $\begin{array}{l}\text { Higher } \\
\text { conc. } \\
\text { /site/season }\end{array}$ \\
\hline Surface & $0.3-8.9$ & $\mathrm{I} / \mathrm{R}$ & $7.14-9.21$ & IV/R & $0.081-0.5$ & III/R \\
\hline $30 \mathrm{~cm}$ & $0.9-12$ & V/R & $7.20-9.33$ & V/R & $0.13-0.62$ & IV/R \\
\hline $\begin{array}{l}\text { ANOVA } \\
\text { results/Source } \\
\text { of variation } \\
\end{array}$ & $\begin{array}{l}\text { Mean } \\
\text { squares }\end{array}$ & $\begin{array}{l}\text { Computed } \\
\text { F value }\end{array}$ & Mean squares & $\begin{array}{l}\text { Computed F } \\
\text { value }\end{array}$ & Mean squares & $\begin{array}{l}\text { Computed } \\
\text { F value }\end{array}$ \\
\hline Sites & 19.27 & $43.92^{* *}$ & 0.70 & $100.6^{* *}$ & $3.44 \mathrm{E}-02$ & $113.29^{* *}$ \\
\hline Seasons & 193 & $387.86^{* *}$ & 10.90 & $2551.4^{* *}$ & 0.214 & $3878.65^{* *}$ \\
\hline Sites X Seasons & 9.40 & $19.35^{* *}$ & 0.11 & $12.89^{* *}$ & $3.44 \mathrm{E}-02$ & $162.5^{* *}$ \\
\hline Depth & 32.93 & $63.65^{* *}$ & 0.200 & $5.33^{* *}$ & $1.06 \mathrm{E}-02$ & $38.09^{* *}$ \\
\hline Sites X Depth & 11.01 & $21.28^{* *}$ & 0.450 & $12.01^{* *}$ & $2.06 \mathrm{E}-02$ & $73.70^{* *}$ \\
\hline $\begin{array}{l}\text { Seasons X } \\
\text { Depth }\end{array}$ & 3.83 & $7.41^{* *}$ & 195E-03 & $5.20 \mathrm{E}-02^{\mathrm{ns}}$ & $5.46 \mathrm{E}-02$ & $194.84^{* *}$ \\
\hline $\begin{array}{l}\text { Sites X Seasons } \\
\text { X Depth }\end{array}$ & 5.67 & $10.96^{* *}$ & 0.224 & $5.98^{* *}$ & $2.266 \mathrm{E}-02$ & $80.81^{* *}$ \\
\hline
\end{tabular}

** = significant at 0.01 level; $*=$ significant at 0.05 level; $\mathrm{ns}=$ non significant

like heart, kidney and liver (Table 11). 
Mathur and Sundaramoorthy Afr J Tradit Complement Altern Med. (2013) 10(1):83-94 90 http://dx.doi.org/10.4314/ajtcam.v10i1.12

Sperm density in testis showed almost normal as that of control. However, in Cauda epididiymis reduction in sperm density in treated group was observed (Table 12). The motility of sperms of Cauda epididiyimis was similar to control (80\%).

Table 10: Soil parameters at the sites of T. terrestris

\begin{tabular}{|c|c|c|c|c|c|c|}
\hline & \multicolumn{2}{|c|}{$\begin{array}{l}\text { Organic carbon (mg } \\
\left.100 \mathrm{~g}^{-1}\right)\end{array}$} & \multicolumn{2}{|c|}{ Nitrogen (mg 100g ${ }^{-1}$ ) } & \multicolumn{2}{|c|}{ Phosphorus (mg 100g ${ }^{-1}$ ) } \\
\hline Sampling & Range & $\begin{array}{l}\text { Higher } \\
\text { conc./site/s } \\
\text { eason }\end{array}$ & Range & $\begin{array}{l}\text { Higher } \\
\text { conc./site/s } \\
\text { eason }\end{array}$ & Range & $\begin{array}{l}\text { Higher } \\
\text { conc./site/seaso } \\
\text { n }\end{array}$ \\
\hline Surface & $\begin{array}{l}23.23- \\
348.6 \\
\end{array}$ & $\mathrm{~V} / \mathrm{S}$ & $14.8-395$ & $\mathrm{I} / \mathrm{S}$ & $6.05-70.27$ & $\mathrm{~V} / \mathrm{R}$ \\
\hline $30 \mathrm{~cm}$ & $\begin{array}{l}53.74- \\
285\end{array}$ & $\mathrm{~V} / \mathrm{S}$ & $12-125$ & $\mathrm{I} / \mathrm{S}$ & $6.02-67.85$ & V/R \\
\hline $\begin{array}{l}\text { ANOVA results/ } \\
\text { Source of } \\
\text { variation }\end{array}$ & $\begin{array}{l}\text { Mean } \\
\text { squares }\end{array}$ & $\begin{array}{l}\text { Computed } \\
\text { F value }\end{array}$ & Mean squares & $\begin{array}{l}\text { Computed } \\
\text { F value }\end{array}$ & Mean squares & $\begin{array}{l}\text { Computed } \mathrm{F} \\
\text { value }\end{array}$ \\
\hline Sites & 9356.4 & $327.57^{* *}$ & 21294.8 & $1187.68^{* *}$ & 603.8 & $159.28^{* *}$ \\
\hline Seasons & 5.5 & $1535.5^{* *}$ & 4763.19 & $5063.86^{* *}$ & 4074.6 & $609.29^{* *}$ \\
\hline Sites X Seasons & 42.32 & $853.84^{* *}$ & 14144.7 & $253.55^{* *}$ & 333.60 & $46.55^{* *}$ \\
\hline Depth & 1777.25 & $2917.32^{* *}$ & 4140.2 & $88.41^{* *}$ & 108.9 & $8.72^{* *}$ \\
\hline Sites X Depth & 13282.7 & $516.89^{* *}$ & 7299.05 & $155.87^{* *}$ & 156.61 & $12.54^{* *}$ \\
\hline Seasons X Depth & 2475.12 & $386.31^{* *}$ & 17486 & $373.43^{* *}$ & 222.01 & $17.78^{* *}$ \\
\hline $\begin{array}{l}\text { Sites X Seasons X } \\
\text { Depth }\end{array}$ & 34.36 & $71.98^{* *}$ & 6088.2 & $130.02^{* *}$ & 171.4 & $13.73^{* *}$ \\
\hline
\end{tabular}

** = significant at 0.01 level; * = significant at 0.05 level; ns = non significant

\section{Histological study}

Testis: After the treatment for 30 days, the testis exhibited arrest of spermatogenesis with varying degree of spermatogenesis arrest and degenerative change in histological architecture. The seminiferous tubule showed shrinkage in the diameter, which is reflecting in the increase in space in between tubules. The primary spermatocytes were visible in seminiferous tubule. Interstice connective tissues in these space exhibited as a vary loose tissues and had atrophic. The Leydig cell showed regression.

Caput epididymis: The caput epididymis histo-architecture showed shrinkage in the epithelia cell height. The lumen was filled either by cell debris or by part of degenerated sperm or devoid of any sperm.

Cauda epididymis: It has also exhibited shrinkage in epithelium. Lumen is either devoid of any content or full of cell debris. Intratubular space showed mark increased.

Seminal vesicle: The histology of treated animal showed normal histo-architecture. The lumen is full of secretion and no shrinkage was reported in the epithelia cell height.

Table 11: Body weight and different organ weight of male mice

\begin{tabular}{|l|l|l|}
\hline Weight (mg/100g body wt) & Control & Treated animal \\
\hline Initial body weight & 30 & 35 \\
\hline Final body weight & 33 & 38 \\
\hline Testis & 466 & 463.7 \\
\hline Epididymis & 248.48 & 218.42 \\
\hline Seminal vesicle & 462.63 & 731.57 \\
\hline Ventral prostrate & 109.09 & 126.37 \\
\hline Heart & 451.57 & 626.31 \\
\hline Kidney & 1290 & 1296.4 \\
\hline Liver (g/100g body wt.) & 4.64 & 4.77 \\
\hline
\end{tabular}

Table 12: Sperm density (Million/ml) and sperm motility (\%) in control and treated mice

\begin{tabular}{|l|l|l|l|}
\hline \multirow{2}{*}{} & \multicolumn{2}{|l|}{ Sperm density } & \multirow{2}{*}{ Sperm motility (\%) } \\
\cline { 2 - 3 } & Testis & Cauda & \\
\hline Control & 4.5 & 35 & 80 \\
\hline $\begin{array}{l}\text { Treated } \\
\text { animal }\end{array}$ & 4.35 & 7.92 & 80 \\
\hline
\end{tabular}


Mathur and Sundaramoorthy Afr J Tradit Complement Altern Med. (2013) 10(1):83-94 91 http://dx.doi.org/10.4314/ajtcam.v10i1.12

\section{Discussion}

Biomass studies of $T$. terrestris carried out at five sites, which were produced considerable effect on root and fruit biomass as well as plant cover, while the site factor was non-significant for stem and leaves biomass. Variation in fruit production and its weight also noticed at different sites. The changes in fruit biomass of $T$. terrestris and its related parameters are significantly changed with sites. The fruit production was favored by soil nitrogen (Fruit $=5689.55$ 287.83+4.04 soil nitrogen; $\mathrm{R}^{2}=0.96 ; \mathrm{P}<0.01$ ) and the root shoot ratio is positively related with soil moisture (root shoot ratio $=0.39-0.11+0.012$ soil moisture; $\mathrm{R}^{2}=0.95 ; \mathrm{P}<0.01$ ). In present investigation, it is noticed that the total carbohydrate in root and shoot inhibit the root and shoot ratio. Goeden and Ricker (1973) reported that incidence of puncture-vine carpels in soil samples decrease with depth, and they established highly significant negative linear correlation of sample depth verses mean number of carpels recorded at each depth. The number of seeds per coccus is as many as 4 with transverse partition between them but cocoi with minimum 3 and maximum 7 seeds are also reported (Joshi et al. 1966).

It is observed that both sites and different plant modules contributed significant variation in protein content in $T$. terrestris. The maximum mean protein was observed at site IV while minimum was at site II. Among the plant parts fruit contained highest plant protein. The soluble and insoluble sugar content were significantly influenced by both site and module factor. Among plant part fruit showed the highest soluble sugar, while leaves at all sites except site II showed minimum sugar content.

The fruits of T. terrestris are known for rich source of steroidal saponin. Steroidal saponins have been reported in almost all parts of this plant. In present investigation among the different plant part the highest concentration was recorded in fruit at all site. In fruit, the maximum concentration was found at site II. The high concentration in fruits explained by the general fact that the steroidal saponin is biosynthesized principally in above ground parts. Dinchev et al. (2008) have reported that steroidal saponin varied with region and plant developmental stages.

Both site and module factors and their interaction produce variation in phenolic concentration. No clear trends have been observed in respect of distribution of phenolic compounds in various modules. Among plant part, the maximum phenol was observed in root of at site II.

In T. terrestris the maximum alkaloids was observed at site IV and the minimum yield was at site II. No major patterns have been recorded between plant part and sites. Among plant parts, the maximum was found in fruits of sites IV. The linear relationship between protein and alkaloid was observed ( alkaloid $=-0.364+0.33$ protein; $\mathrm{R}^{2}=0.99 ; \mathrm{P}<0.01$ ) for fruit module. The positive correlation between both these parameters can be explained by the simple fact that both having nitrogen content.

The results showed the low availability of Zn content in fruit part at all sites, and this can be explained by the antagonistic nature of zinc and iron in plant. In present investigation, the fruits possess higher iron level at all with lower zinc content. These results are in agreement with Grusak (1994) who reported that iron has been loaded into developing ovules of peas (Pisum sativum L.) via the phloem in an unknown Fe-chalet complex.

The soils from $T$. terrestris sites showed more moisture at depth during all season. The exception in this trend was observed at site I during rainy period where surface soil showed more moisture compare to depth. The above results are in agreement of studies of various workers (Bhandari, 1977, Lekhak, 1983, Mishra, 1985, Kasera, 1988, Mohammed, 1988).

During wet period most of sites showed high EC at $30 \mathrm{~cm}$ depth, while during winter season the reverse trend was observed at most sites with exception of site II, which showed more EC at depth. The data revealed that mean EC concentration with respect of season followed the simple trend i.e. rain>winter>summer, the exception being at site II (winter>summer $>$ rain).

The analysis of soil organic carbon from $T$. terrestris sites revealed that at sites namely I, II, III and IV, the maximum organic carbon at observed during rainy period followed by winter and summer, whereas at V site it was in order of summer>rain>winter. At depth, no distinct patterns have been observed.

Soil from $T$. terrestris habitats showed that mean $\mathrm{N}$ content was the maximum during summer period at three sites namely I, IV, and V that was followed by winter and rain. The results are in agreement of studies of Singh (1984).

The P concentration in the soil of $T$. terrestris habitats showed same trend i.e. highest during rainy season followed by winter and summer season. The only exception in that trend was recorded at site I where the summer P concentration was higher then winter P. No general trend was recorded in respect of different soil profiles.

Study of seasonal pattern of available P indicating more P concentration during rainy period compared to cool and dry periods. It is most likely due to regulation of soil microbes. Sparling et al. (1985) and Qiu and Mccomb (1995) reported that drying and rewetting increase the release of $\mathrm{P}$ from air-dried soils and sediments. A significant proportion of P released is probably due to effects of drying and rewetting on the microbial biomass. Qiu and Mccomb (1995) attributed the entire increase in soil P on air-drying to killed microbial cells. He and Zhu (1998) reported that of the adsorbed P transformed by microbes from soil, $17-34 \%$ was water soluble and available P. This clearly indicates microbial turnover to be the cause of increase in available P during wet season. The results are in agreement with those reported by Rao and Tarafdar (1992) where in maximum available $\mathrm{P}$ was recorded during rainy season.

Linear relation between soil moisture and $\mathrm{pH}\left(\mathrm{pH}=7.74+0.173\right.$ moisture; $\left.\mathrm{R}^{2} 0.741 ; \mathrm{P}<0.01\right)$ and between $\mathrm{pH}$ and EC $\left(\right.$ Ec $\left.-0.621+0.10 \mathrm{pH} ; \mathrm{R}^{2}=0.642 ; \mathrm{P}<0.01\right)$, and this relation between $\mathrm{pH}$ and $\mathrm{EC}$ can be explained by the fact that high $\mathrm{pH}$ value supports increase level of $\mathrm{Na}$ or $\mathrm{Ca}$ or both, that represent the saline or sodic soil. Logarithmic path between moisture and $\mathrm{EC}$ also exist $\left(\mathrm{Ec}=0.23+0.006 \log\right.$ moisture; $\left.\mathrm{R}^{2}=0.652 ; \mathrm{P}<0.01\right)$ and this result are in agreement of study of Abrol et al. (1988) suggesting that unit depth of water can remove nearly 80 percent of salts from a unit soil depth. However both soil moisture and available $\mathrm{P}$ are related with each other in logarithmic manner $\left(\log \mathrm{P}=13.28-0.48 \log\right.$ moisture; $\mathrm{R}^{2}=0.82$; 
$\mathrm{P}<0.01$ ), Grierson et al. (1999) reported that the increase of water potential and temperature increases specific $\mathrm{P}$ mineralization.

Since the precursor produced during photosynthesis also form the backbone for the synthesis of secondary metabolites. The physio-ecological role of different environment factors and the responses of plant synthesizing special product under different irradiances may be extraordinarily diversified. Through chemical, physical and biological means, soil has a complex effect on the growth, development, dry-matter production, and special product production of plant. In our study the relationship between soil nutrient and plant secondary metabolites are established. Parabolic relation between soil nitrogen and fruit alkaloid (alkaloid $=8.94-0.654+0.001 ; \mathrm{R}^{2}=0.82 ; \mathrm{P}<0.05$ ) exist and this results are supported by various workers like Naumova and Scberstov, (1972), Waller and Nowacki, (1978). Soil pH and fruit alkaloid also related in exponential path (alkaloid = $1.31 \mathrm{E}-10-2.56 \mathrm{pH} ; \mathrm{R}^{2}=0.89 ; \mathrm{P}<0.05$ ) and supported by McNair $(1942)$.

The effect on body weight after the treatment of test substance is an important yardstick of the anabolic and catabolic mode of action and the general metabolic status of the animal. In present investigation increase in the final body weight in control and with the administration of $T$. terrestris fruit observed.

Testicular size is the best primary assessment of function of testis; since around $98 \%$ testicular maps is made-up of tubules and germinal epithelium. Testicular size indicates the status of spermatogenesis. Miskin and Bain (1978) reported that size of the testis bear direct relationship with number of sperm produce. In current investigation decrease in weight of testis were observed. It is well establish fact that structural and functional integrity of reproductive organs depends upon circulating androgen (Chinoy et al., 1982; Brooks, 1983). Any changes in alternation of androgen level results in general decrease in testicular weight and inhibition in accessories (Oko and Hrukda, 1984). Reduction in weight of testis indicates that circulating testosterone was not enough to maintain the weight of gonads. Reduced concentration of androgen and FSH must have resulted in arrest of spermatogenesis. As consequences of the arrest of spermatogenesis, testicular fall in weight was also associated with shrinkages in seminiferous tubules.

Epididymal canal represent the site where the spermatozoa undergo morphological, physiological and biochemical changes culminating in their functional maturation. The epididymis provides the favorable milieu for survival and vigor of spermatozoa. Though the initiation of spermatogenesis take place in testis, the transport, storage, capacity and nutrition of spermatozoa are totally depends on the sexual and accessory reproductive organs. Thus the maintains of accessories like epididymis, seminal vesicle and ventral prostrate is essential. Its known that changes in androgenic status of the animal alter the pattern of cellular proliferation in accessory reproductive organ (Prasad and Vijayan, 1987). The increase in weight of seminal vesicle was due to increase in secretion. The secreting function of seminal vesicle is depending upon androgenic level.

Prostrate gland of mice contains certain androgenic receptors (Prins et al. 1991). The androgenic property of plant product must have caused increase in weight of ventral prostrate also observed.

In present investigation the reduction in sperm counts contemplate because of actual consequences of suppression of spermatogenesis, due to disturbance in normal testicular function. Since FSH and testosterone are proximally required by stertoll cell to support spermatogenesis (Carr and Griffin, 1992). They act synergistically, and influence the different steps of sperm cells, transformation during spermatogenesis (Shetty et al. 1996). Depletion in the biosynthesis of these hormones due to external androgen could block spermatogenesis.

From above histological architecture and sperm density of different treated groups revealed that these drugs extract possess androgenic compounds, which contributes external amount of testosterone. This amount of testosterone slightly increases the weight of accessories reproductive organ but this amount is not modifying drastically reproductive function. Reduction in sperm density and sperm motility in Cauda and testis is due to negative feedback to the hormonal system. This less amount of testosterone inhibits the sperm density that clearly demonstrates the androgenic nature of these plant products. The vital organs of animal reflect normal histology, which show drugs are not having toxic effect or they are free from toxic. In treated group the weight of seminal vesicle and ventral prostrate significantly increase due to androgenic nature of plant product. The histo-architecture of seminal vesicle in all treated groups reflects increase in the secretion, which further confirms the androgenic nature of plants.

Conclusion

In our study it can be predicted that pharmacological activities of fruit part of $T$. terrestris depends on the proportions of different metabolites. The synergism of different metabolites are observed on the body weight, reproductive parts like seminal vesicle, ventral prostrate and vital organs like heart, kidney, and liver. However the antagonistic nature between different metabolites specially with steroidal saponin (known to be the active compounds of this plant and support the reproductive activities in male mice) have been reflected on testis and epididymis weight and on sperm density in cauda that could cause significant reduction compare to control.

Since the plant possessed the aphrodisiac properties, and a part of several herbal tonic and medicine therefore site III can be suggested as the most suitable for maximum production of different metabolites on the basis of standing state (biomass and concentration of metabolites) quantification.

\section{Acknowledgment}

The authors are grateful to Professor and Head, Department of Botany and Zoology for facilities. One of the authors (Manish Mathur) is grateful to the Director CAZRI, Jodhpur for study leave that facilitated this research. 


\section{References}

1. $\quad$ Abrol, I.P., Yadav, J.S.P. and Masoud, F.I. (1988). Salt affected soils and their management. FAO Soils Bull., $39: 131$.

2. Ageel, A.M., Islam, M.W., Ginawi, O.T. and Al-Yahya, M.A. (1994). Evaluation of the aphrodiasic activity of Lisea chinensis (Lauraceae) and Orchis malculata (Orchidaceae) extract in rats. Phytother. Res., 8: 103-105.

3. Allen, S.E., Grimshaw, H.M., Parkinson, J.A., Quarmby, C. and Roberts, J.D. (1976). Chemical analysis In: Methods in Plant Ecology (ed.) S.B. Chapman. Blackwell Scientific Publications, Oxford, pp. 536.

4. Ang, H.H., Nagi, T.H. and Tan, T.H. (2003). Effect of Eurycoma longifolia Jack. on sexual qualities in middle aged male rats. Phytomedicne. 10: 509-593.

5. $\quad$ Auger, J. (1995). Decline in sperm quantity among fertile men in Paris during the past 2020 years. New Eng. J. Med. 332: 281285.

6. Baccou, J.C., Lambert, F. and Sauvaire, Y. (1977). Spectrophotometric method for the determination of total steroidal saponin. Analyst 102: 458-465.

7. Bakshi, N. 1954. The morphology and ecology of Mollugo cerviana Ser. J. Indian Bot. Soc. 52: 484-512.

8. Bernath, J. 2002. Production ecology of secondary plant products. In: Herbs, Species, and Medicinal Plants (eds.) L. E. Craker and J.E. Simon, CBS Publishers and Distributers, New Delhi, India, Vol. 1 pp. 185-234.

9. Bhandari, D.C. (1977). Studies on arid zone legumes with special references to Indigofera species- their ecology, nitrogen metabolism and role in crop ecosystem. Ph.D. Thesis, Univ. of Jodhpur, Jodhpur, India

10. Bradford, M. (1976). A rapid and sensitive method for the quantitation microgram quantities of protein utilizing the principle of protein - dye binding. Anal. Biochem. 72: 248-254.

11. Brooks, D.E. (1983). Epididiymal function and their hormonal regulation. Aust. J. Boil. Sci. 36: 205-208

12. Carr, B.R. Griffin, J.E. (1992). Fertility control and its complication. In: Textbook of Endrocrinology. (eds.) J.D. Wilsen, and D.W. Foster. W.B. Saunders Company, Harcourt Brace, Joranrich, Inc. Philadelphia.

13. Chinoy, N.J., Sheth, K.M. and Sethalakshmi, L. (1982). Studies on reproductive physiology of animal with special references to fertility control. Comp. Physiol. Ecol. 7: 325

14. Daniel, M. (1991). Methods in Plant Chemistry and Economic Botany Kalyani Publishers, New Delhi pp. 194 p.

15. Dinchev, D., Janda, B., Liuba, E., Oleszek, W., Aslani, M. and Kostova, I. 2008. Distribution of steroidal saponins in Tribulus terrestris from different geographical regions. Phytochemistry 69: 176-186.

16. Gauthaman, K. Adaikan, P.G. and Prasad, R.N. (2002). Aphrodisiac properties of Tribulus terrestris extract (Protodioscin) in normal and castrated rats. Life Sci. 71: 1385-1396.

17. Gauthman, K. Ganesan, A.P. and Prasad, R.N. (2003). Sexual effects of punctuervine (Tribulis terrestris) extract (protodioscin) an evaluation using a rat model. AJTCAM. 9: 257-265

18. Goeden, R.D. and Ricker, D.W. (1973). A soil profile analysis for puncturevine fruit and seed. Weed Sci. 21: 504-507.

19. Gomez, K.A. and Gomez, A.A. (1984). Statistical Procedures for Agricultural Research $2^{\text {nd }}$ ed., John Wiley \& Sons, New York, USA.

20. Grierson, P.F. and Comeford, N.B. and Jokela, E.J. (1999). Phosphorus mineralization and microbial biomass in a Florida spodosal: Effects of water potential, temperature and fertilizer application. Biol. Fertil. Soil 28: 244-252.

21. Grusak, M.A. (1994). Iron transport to developing ovules of Pisum sativum L. Seed important characteristics and phloem iron loading capacity of source region. Plant Physiology 104: 649-655

22. He, Z.L. and Zhu, J. (1998). Microbial utilization and transformation of phosphate adsorbed by variable charge minerals. Soil Biol. Biochem. 30: 917-923.

23. Higuch, T. and Bodin, J. I., 1961. Alkaloida and other basic nitrogenous compounds- pharmaceutical analysis. (eds.) T. Higuchi, and E. B. Hansen, pp. 315-345.

24. Irvine, S., Cawood, E., Richardson, D., MacDonald, E. and Aitken, J. (1996). Evidence of deteriorating semen quality in the United Kingdom: Birth cohort study in 577 men in Scotland over 11 years. Br. Med. J. 312: 467-471.

25. Jackson, M.L. (1973). Soil Chemical Analysis. Prentice Hall Inc. Engewood Cloff, N.J.

26. Joshi, M.C., Kahate, S. and Bishnoi, S. (1966). Autecological studies on Rajasthan desert plant Tribulus terrestris (Linn). J. Econ. Taxon. Bot. 169-184.

27. Kasera, P. K. (1988). Arid agro-ecosystem: Weed biology and weed management. Ph.D. Thesis, Univ. of Jodhpur, Jodhpur, India.

28. Kent, M. and Cooker, P. (1992). Vegetation Description and Analysis. Bekhaven

29. Press, London

30. Kumar, P.K.S., Subramaniam, A. and Pushpangadan, P. (2000). Aphrodisiac activity of Vanda tessellate (Roxb.) root extract in male mice. Indian J. Pharamacol. 32: 300-304.

31. Lekhak, H.D. (1983). Plant life with special reference to leaf and stomatal behavior in Indian desert. Ph.D. Thesis, Univ. of Jodhpur, Jodhpur.

32. Marimuthu, P., Kapilashranmi, M.C., Misra, M.M. and Singh, G. (2003). Evaluation of trend in semen analysis for 11 years in subjects attending a fertility clinic of India. Asian J. Androl. 221-225.

33. Mathur, M and Sundaramoorthy, S. (2009). Mineral compostion in Chorchorus depressus at heterogenous environmental conditions and their relationships with bottom-up, top-down, and plant metabolite factors. Comm. Soil Sci. Plant Anal., 40: $2028-2043$.

34. Mathur, M. (2005). Ecology and prospecting of some medicinal plants of aphrodisiac potentials. Ph. D. Thesis. Jai Narain Vyas University, Jodhpur.

35. Mathur, M. (2012). Herbal Aphrodisiac their need, biology and status: global and regional scenario. JNP, 5: 131-145.

36. Mathur, M., Purohit, A., and Sundaramoorthy, S. (2008). Ecological and pharmacological studies of an aphrodisiac plant Corchorus depressus (Linn.). Hamdard Medicus., 51 (4): 73- 92.

37. Mathur, M., Sundaramoorthy, S. (2006). Ecological and aphrodisiac properties of Blepharis sindica. Nig. J. Nat. Prod. and Med., 10: $17-25$

38. McNair, J.B. (1942). Soil acidity in relation to alkaloid and cyanogentic glucoside production. Lloydia., 25: 208

39. Menchinick, E.F. (1964). A comparison of some species individual diversity indices applied to samples of field insect. Ecol., 45: 859-861.

40. Mishra, R.K. (1985). Role of legumes in crop production and weed management in Indian arid zone. Ph.D. Thesis, Univ. of Jodhpur, Jodhpur, India. 
Mathur and Sundaramoorthy Afr J Tradit Complement Altern Med. (2013) 10(1):83-94 94 http://dx.doi.org/10.4314/ajtcam.v10i1.12

41. Miskin, M. and Bain, J. (1978). The use of diagnostic ultrasound in evaluation of testicular disorder. In: Progress in Reproductive Biology. Andrology, Basic and Clinical aspects of Male Reproductive and Infertility (eds.) J. Bain, E.S.E. Hafez and B.N. Barwin. Karger Publ., Vol. 3: 117 pp.

42. Mohammed, S. (1988). Comparative studies of saline and nonsaline vegetation in Indian arid zone. Ph.D. Thesis, Univ. of Jodhpur, Jodhpur, India.

43. Mukherjee, T. (2004). Medicinal plant: Need for protection. In: Medicinal Plant Utilization and Conservation,(ed.) P.C. Trivadi. Avaishkar Publishers, Jaipur, pp. 391-404.

44. Nair, N.C. (1956). Flora of Chirawa. Proc. Rajasthan Acad. Sci., 6: 49-64

45. Nair, N.C. and Malhotra, S.K. (1961). A study of the vegetation of Lohargal and its neighborhood. Bull. Bot. Survey India., 3: 139-151.

46. Nair, N.C. and Nathawat, G.C. (1957). Vegetation of Harsnath, Aravalli hills. J. Bombay nat. Hist. Soc., 54: $281-301$.

47. Naumova, G.E. and Seberstov, V. (1972). vlianii fosfora na urhosai manshithnovo maka I shoderjani alkaloidov. Agrochimiya (Moscow)., 5: 36-39.

48. Oko, R. and Hrukda, F. (1984). Comparison of the effect of gossypol, estradiol 17 beta and testosterone on composition of male reproductive organs. Biol. Reprod., 30: 1198-1207.

49. Pallavi, K.J., Singh, R., Singh, S., Singh, K, Farswan, M., Singh, V. (2011). Aphrodisiac agents from medicinal plants: a review. J. Chem. Pharma. Res., 3 (2): 911-921.

50. $\quad$ Pandeya, S.C., Puri, G.S. and Singh, J.S. (1968). Research Methods in Plant Ecology. Asia Publishing House, London, U.K.

51. Pielou, E.C. (1966). Species diversity and Pattern of diversity in the study of ecological sucession. J. Theory Biol., 10: $370-383$.

52. Plummer, D.T. (1971). An Introduction to Practical Biochemistry. Tata McGraw Hill, Publisher New Delhi

53. Prasad, M.R.N., Chinoy, N.J. and Kadam, K.H. (1972). Changes in succinate dehydrogenate levels in the rat epididymis under normal and altered physiological conditions. Fertil. Steril., 23: 186-190.

54. Prasad, R.S. and Vijayan, E. (1987). A new non-hormonal antifertility drug DL-204: Effect on tests and accessory glands of reproduction in male rats. Contraception, 36: 557-556.

55. Prins, G., Birch, L. and Greene, G. (1991). Androgen receptor localization in different cell types of the adult rat prostate. Endocrinology, 129: 3187-3199.

56. Qiu, S. and McComb, A.J. (1995). Planktonic and microbial contributions to phosphorus release from fresh and air-dried sediments. Marine Freshwater Res., 46: 1039-1045.

57. Quershi, S., Shah, A.H., Tariq, M. and Ageel, A.M. (1989). Studies on herbal aphrodisiac used in Arab system of medicine. Am. J. Chin. Med., 17: 57-63.

58. Ramachandran, S., Sridhar, Y., Sam, S.K., Saravanan, M. Leonard, J.T., Anbalagan, N., and Sridhar, S.K. (2004). Aphrodisiac activity of Butea frondosa Koen. Ex Roxb. extract in male rats. Phytomedicine., 11: 165-168.

59. Rao, A.V. and Tarafdar, J.C. (1992). Seasonal changes in available phosphorus and different enzyme activities in arid soil. Ann. Arid Zone., 31: 185-189.

60. Ratnam, B.V. (1951). The vegetation of Lohargal. Proc. Rajasthan Acad. Sci. 2: 26-36.

61. Ratnam, B.V. and Joshi, M.C. (1952). An ecological study of the vegetation near about temporary pound in Pilani. Ibid., 3: 4559.

62. Shetty, J., Marathe, G.K., Ramaswamy, S. and Dighe, R.R. (1996). Pituitary gonadotropin regulate spermatogonial differentiation and proliferation in the rat. J. Bio. Sci., 21: 82-92.

63. Simpson, E.H. (1949). Measurement of diversity. Nature 163: p. 668.

64. Singh, H.P. (1984). Soil physical constraints in relation to increasing the arid zone productivity with particular references to agroforestry. In: Agroforestry in Arid and Semi-arid Zones, (ed.) K.A. Shankarnarayan, CAZRI, pp. 30-32

65. Sparling, G.P., White, K.N. and Ramsay, A.J. (1985). Quantification the contribution from the soil microbial biomass to the extractable P levels of fresh and air-dried soils. Aust. J. Soil Res., 23: 613-621.

66. Suja, S.R., Latha, P.G., Pushpangadan, P. and Rajasekharan, S. (2002). Aphrodisiac property of Helminthostachys zelanica in male mice. J. Trop. Medicinal Plants., 3: 191-195.

67. Verdu, A.M.C., and Mas, M.T., 2006. Cohort-dependent seedling recruitment, survival and reproductive capacity of Tribulus terrestris. Weed Research, 46: 371-378-382

68. Waller, G.R. and Nowacki, E.K. (1978). Alkaloid Biology and Metabolism in Plants. Plenum press, New York, 294 p. 